\title{
Entrepreneurship and Entrepreneurial Skills in Middle School Mathematics Lesson Curriculum and Teaching Profession Through the Eyes of Pre-service Elementary Mathematics Teachers
}

\author{
Elif Nur AKKAS \\ Faculty of Education, Bolu Abant Izzet Baysal University, 14100, Bolu, TURKEY
}

\begin{abstract}
These days, when the age of industrial society has passed to the age of information and technology, the profile of people with intelligent, logical, and practical intelligence stands out instead of the labor force. In this sense, education is the most important element in the education of entrepreneurial individuals who can keep up with the rapid changes of the age. Entrepreneurship trainings are also important for individuals to gain entrepreneurship and entrepreneurial skills. These trainings are usually given at the university level. At this point, the main goal in entrepreneurship education is to introduce entrepreneurship, and to educate entrepreneurial individuals. The aim of this research was to examine the thoughts and knowledge of pre-service elementary mathematics teachers about the concepts of entrepreneurship and entrepreneurial skills from the point of view of the middle school mathematics course curriculum, as well as from the point of view of the teaching profession. Qualitative research was used in the research. A total of 40 pre-service elementary mathematics teachers, including 10 pre-service teachers ( 5 females and 5 males) from each year of study, who were studying at a Faculty of Education. The data was collected using a semi-structured interview form. The interview form consisted of 5 questions. The content analysis technique was used in the data analysis. The findings of the middle school mathematics curriculum in entrepreneurship and entrepreneurial skills of entrepreneurship and entrepreneurial skills in the place and on the importance of the teaching profession and the faculty were examined under 2 titles. All of the first-year preservice teachers stated that they had never studied the curriculum in terms of entrepreneurship and entrepreneurial skills. Pre-service teachers have skills that can be associated with entrepreneurial skills, creativity, problem solving, communication, critical thinking, and forecasting skills. Mathematics lessons are taught the most by pre-service teachers to help them gain entrepreneurship skills. The importance of having entrepreneurship and entrepreneurship skills for the teaching profession, in terms of the teacher-student and teacher-teaching processes. All of the pre-service teachers stated that they had not taken courses on entrepreneurship. The concepts of entrepreneurship and entrepreneurship skills, whose place and importance are increasing day by day, should be included more in curricula and their importance in terms of teaching should be taught.
\end{abstract}

Keywords: Entrepreneurship, Entrepreneurial Skills, Entrepreneurship Education, Pre-service Elementary Mathematics Teachers

DOI: $10.7176 / \mathrm{JEP} / 12-5-06$

Publication date: February $28^{\text {th }} 2021$

\section{Introduction}

Entrepreneurship is a frequently encountered expression in daily life, especially in the business, industry and economy sectors. The reason why this concept, which has been explored frequently in recent years, has become popular, is that it contains many disciplines and this dynamism has been newly discovered (Schumpeter, 1991). However, since entrepreneurship is constantly dynamic, it is not possible to come across a single definition of this concept. With the definition of usable in the business-industry sector, entrepreneurship can be defined as the process in the emergence of new things, as well as gain and risk estimation (Hisrich \& Peter, 1998). In general terms, this concept can be associated with turning the surrounding situations into opportunities and creating new opportunities (Bozkurt, 2007).

These days, when the age of industrial society has passed into the age of information and technology, the human profile with intelligent, logical, and practical intelligence stands out instead of the workforce. In this sense, the most important element in raising entrepreneurial individuals who can keep up with the rapid changes of the age is education. Education is one of the biggest contributing factors in the acquisition and development of entrepreneurship and entrepreneurship skills in individuals. In this direction, entrepreneurship trainings carried out to increase entrepreneurial activities are also transferred to individuals within the framework of each country's unique cultural context (Lee \& Peterson, 2000). With the developments in this direction, there was an increase in the number of entrepreneurship courses in different universities in many countries of the world in the 2000s (Finkle et al., 2006). The concept of entrepreneurship and entrepreneurial skills in Turkey, as well as a variety of business sectors, especially in the Ministry of Education, has been on the agenda. The Ministry of 
National Education (2005) has adapted this concept to the education process by defining entrepreneurship as "empathizing, showing harmonious behavior in human relations, planning, implementing the plan, taking risks and recognizing the required product in any field". In the later years, considering the general competencies of the teaching profession, it was emphasized that teachers and teacher candidates should have entrepreneurial characteristics and be able to integrate this process into the program (Ministry of National Education [MEB], 2013). Thus, entrepreneurship, from elementary school in Turkey, is a concept that has been encountered at all levels of education up to secondary education (Ministry of National Education [Ministry of Education], 2018). When the definition of entrepreneurship by the Ministry of National Education (2005) was examined, the concepts of noticing events, finding solutions to problems, and taking lessons from the process came to the forefront, as entrepreneurship is a thinking process. At this point, it comes to mind that thinking individuals can evaluate the problems that they encounter from a different perspective, find solutions, and gain experience by taking lessons from events (Ergüven, 2011). Thus, it can be considered that the concept of entrepreneurship encourages individuals to use their critical thinking, creative thinking, and problem solving skills. It is a fact that educational institutions, in addition to being the foundation of the education system, play a major role in providing students with skills that will enable them to be successful in individual and social fields. In this sense, the curriculum of the courses taught in Turkey, as well as the above mentioned skills, entrepreneurial skills is also replaces the (Ministry of Education [Ministry of Education], 2005).

Entrepreneurship skill is expressed in the form of "all learning activities related to personal, social and working life of the individual in order to advance the knowledge, skills and competencies of the individual and take it one step further" (European Commission, 2006). At the same time, it is a necessary skill to put into action the feelings and thoughts of the individual, plan to achieve the targeted goal, manage the process, and realize risk-taking, creative, and innovative skills (Figel, 2007, 3-12). When the skills and entrepreneurship skill definitions found in thinking individuals were compared by Ergüven (2011), it can be said that the entrepreneurship skill included critical thinking, creative thinking, and problem solving skills.

Entrepreneurship trainings are provided to realize entrepreneurship skills. Sánchez (2013: 448) pointed out that the assumption underlying entrepreneurship education programs is that entrepreneurship-related skills are not a matter of personality and can be taught. The main purpose of entrepreneurship training is that it is the acquisition of both entrepreneurship awareness and entrepreneurship skills (A $\breve{g c a}, 2007$ ). These trainings are usually given at the university level. The common goal of the trainings on entrepreneurship and entrepreneurship skills in universities is to enable students to establish a business using their creative, critical, and innovative ideas in different fields and business lines (Bozkurt, 2011). There may be some differences in the trainings for entrepreneurship and entrepreneurship skills. At this point, while the main purpose of entrepreneurship training is to introduce entrepreneurship and raise entrepreneurial individuals, the aim of the trainings aimed at gaining entrepreneurship skills is the importance of providing the knowledge and skills required to start the enterprise (Özdemir, 2016). It is expected that the entrepreneurship trainings provided by universities will give priority to changes in both micro and macro features in society (Bulut \& Aslan, 2014). However, when the national and international literature was examined, it was found that these concepts were mostly focused on entrepreneurship training in areas such as social sciences, economics and administrative sciences, and engineering (Wang \& Wong, 2004; İşcan \& Kaygın, 2011; Uygun, et al., 2012; Bilge and Bal, 2012; Korkmaz, 2012; Pan \& Akay, 2015). Expressing entrepreneurship education as a process, Fayolle (2006: 702) pointed to a pedagogical program or training process that includes the acquisition of attitudes, skills, and personal qualities related to entrepreneurship. In this direction, it would be appropriate to provide training on entrepreneurship and entrepreneurship skills at the education faculties of universities. However, these trainings should not only be given in classrooms in the school environment, but should also continue outside the classroom and should be a part of daily life (Selanik Ay \& Acar, 2016). As Solomon stated, the essence of entrepreneurship education should reflect reality (Solomon, 2007: 174). In this case, it can be considered that the entrepreneurship education given in the classroom will be disconnected from real life and these trainings will not reflect a real situation.

In entrepreneurship education, students are expected to turn entrepreneurship education into practice (Clegg, et al., 2005). It is important that entrepreneurship education gives the opportunity to reveal the talents and skills of the people who receive training, rather than being a strict, prescriptive, and completely result-oriented education (Bulut \& Aslan, 2014). In this respect, it can be thought that the courses on entrepreneurship and entrepreneurship skills that will be given in the faculty of education will activate the thinking processes of the pre-service teachers and, at the same time, provide success in creating different initiatives for their students in their assigned schools.

It is believed that this study will make important contributions to the literature due to the stated reasons. First of all, in this area, it was seen that elementary school mathematics teachers and pre-service teachers have never studied what they thought about entrepreneurship and entrepreneurship skills in the middle school mathematics curriculum and teaching profession. With this study, it will be determined how well pre-service teachers know the concepts of entrepreneurship and entrepreneurship skills in the mathematics curriculum before 
starting their profession. In addition, if they take a course called entrepreneurship at the faculty, the contribution of this training to pre-service teachers, and which courses can be effective in gaining entrepreneurship skills, will be examined. Based on these examinations, the needs in the educational process will be determined and the way to provide more frequent use of entrepreneurship and entrepreneurship skills in daily life and mathematics education will be paved. In addition, this study is thought to be a guide for developmental research to be conducted on entrepreneurship in teacher education. The purpose of this study was to examine the thoughts and knowledge of pre-service elementary school mathematics teachers about the concepts of entrepreneurship and entrepreneurship skills in terms of the elementary school mathematics curriculum, as well as the teaching profession, in addition to being a lesson to be learned. For this purpose, the study sought answers to the following questions:

1) Did the pre-service elementary school mathematics teachers encounter the concepts of entrepreneurship and entrepreneurship skills in the middle school mathematics curriculum?

2) If the concepts of entrepreneurship and entrepreneurship skills were included in the middle school mathematics curriculum, how were these concepts addressed in the curriculum?

3) Were there skills that served entrepreneurship skills in the middle school mathematics curriculum? If so, what were these skills?

4) According to pre-service elementary school mathematics teachers, what were the courses that helped to gain entrepreneurship skills?

5) According to pre-service elementary school mathematics teachers, how important is having entrepreneurship and entrepreneurship skills for the teaching profession?

6) Did the pre-service elementary mathematics teachers take a course aimed at gaining entrepreneurship skills in their education faculty? If they did, did they think it was useful?

\section{Methodology of the Research}

\subsection{Research Design}

In this study, it was aimed to reveal the thoughts and knowledge of the pre-service teachers studying in elementary school mathematics, teaching from the 1st to the last year, about the concepts of entrepreneurship and entrepreneurship skills in terms of the middle school mathematics curriculum and teaching profession. Qualitative research was used as a research design.

\subsection{Participant}

Participants of the study consisted of a total of 40 pre-service teachers, comprising 10 teachers ( 5 females and 5 males) from each year of study, who were studying at an education faculty. The reason for choosing pre-service teachers from each year of study was to investigate the opinions and knowledge of the pre-service teachers, in terms of entrepreneurship and entrepreneurship skills, middle school mathematics curriculum, and teaching profession, and examine this situation according to their year of study. Pre- service elementary mathematics teachers were determined from the purposeful sampling types using the maximum diversity sampling method. In the selection of the participants, attention was paid to their volunteerism for the research.

\subsection{Data Collection}

Data were collected using a semi-structured interview form. While preparing the interview form, help was taken from the literature and in this direction, 5 questions were prepared to reveal the knowledge and thoughts of the pre-service teachers about entrepreneurship and entrepreneurship skills in terms of the middle school mathematics curriculum and teaching profession. The prepared interview form was first sent to a language expert and evaluated in terms of Turkish language usage. The interview form, which was arranged according to the feedback, was presented to 4 pre-service teachers who were studying in the 1st, 2nd, 3rd and 4th year, and the pilot study of the interview form was carried out. After the pilot interviews, the final form of the interview form was decided upon. The questions in the interview form consisted of 2 parts. The 2 questions in the first part were about what the pre-service teachers knew about entrepreneurship and entrepreneurship skills in the middle school mathematics curriculum. The 3 questions in the second part were aimed at revealing their knowledge about the importance of having entrepreneurship and entrepreneurship skills, in terms of the teaching profession and their contribution to teachers. Before conducting the interviews, the researcher paid attention to the volunteerism of each pre-service teacher and stated to the participants that the interviews would be recorded on an audio recording. Before conducting the interviews, the researcher explained that the interviews did not qualify as exams, but only an attempt to determine their thoughts about this subject in order to prepare each pre-service teacher for the interview. The interviews lasted approximately $30 \mathrm{~min}$ for each pre-service teacher. The order of presentation of the questions in the interview form was the same for each pre-service teacher. 


\subsection{Data Analysis}

The content analysis technique was used in the analysis of the collected data. The analysis was carried out in 3 stages. First of all, the data obtained as audio recordings were analyzed and the analyses were checked by a person outside of the research. Next, the data were coded by the researcher. Separately, the data were analyzed by a different researcher, and $88 \%$ agreement was found between the codes. In the separate codes, the data and codes were revisited and rearranged according to the consensus reached among the researchers.

\subsection{Reliability and Validity}

In order to increase the internal validity of the research, the literature was taken into consideration while preparing the interview questions. Integrity was ensured by checking the compatibility of the codes and themes obtained from the data. In order for the pre-service teachers to express their opinions without any concern, the researcher gave information about the content of the research and its lack of an examination quality before the interview with the pre-service teachers. Thus, it was ensured that the data collected during the interview process reflected a real situation. In order to increase the external validity of the study, the research design, participants, data collection tool-process, analysis, and interpretation of the data were detailed. In order to increase the internal reliability of the research, the findings were given directly without any comments. After the coding obtained from the data was made by the researcher, another researcher, who different from the first researcher, was allowed to code, and the percentage of compliance was calculated by combining the resulting codes. In order to increase the external reliability of the research, the work done during the research process was specified in detail. At the same time, the data constituting the research were kept by the researcher with the thought that they could be examined later.

\section{Findings}

In this study, which investigated the knowledge and thoughts of pre-service teachers about entrepreneurship and entrepreneurship skills in the middle school mathematics curriculum and the teaching profession, the data were analyzed under 2 headings: the place of entrepreneurship and entrepreneurship skills in the middle school mathematics curriculum and the importance of entrepreneurship and entrepreneurship skills in the teaching profession and the education process in the faculty. As a result of the analysis, the knowledge and opinions of the pre-service teachers were analyzed by giving specific codes and frequency tables.

\subsection{Findings about the Place of Entrepreneurship and Entrepreneurship Skills in the Middle School Mathematics} Curriculum

In the interview questions, first, the pre-service teachers were asked: "Have you encountered the concepts of entrepreneurship and entrepreneurship skills in the middle school mathematics curriculum?" The question was posed. The answers given by the teacher candidates regarding this question are presented in Table 1 .

Table 1. Situation of the pre-service elementary school mathematics teachers to encounter the concepts of entrepreneurship and entrepreneurship skills in the middle school mathematics curriculum according to their year of study.

\begin{tabular}{|c|c|c|c|c|}
\hline & \multicolumn{3}{|c|}{ Frequency } & \multirow[b]{2}{*}{$\begin{array}{l}4 \text { th } \\
\text { year }\end{array}$} \\
\hline & $\begin{array}{c}1 \mathrm{st} \\
\text { year }\end{array}$ & $\begin{array}{l}\text { 2nd } \\
\text { year }\end{array}$ & $\begin{array}{l}\text { 3rd } \\
\text { year }\end{array}$ & \\
\hline $\begin{array}{l}\text { I know the places where these concepts are used in the middle } \\
\text { school mathematics curriculum }\end{array}$ & & & 3 & 7 \\
\hline $\begin{array}{l}\text { I have never encountered these concepts in the middle school } \\
\text { mathematics curriculum }\end{array}$ & & 4 & 2 & 1 \\
\hline $\begin{array}{l}\text { I have never studied the middle school mathematics curriculum in } \\
\text { this direction }\end{array}$ & 10 & 6 & 5 & 2 \\
\hline Total & 10 & 10 & 10 & 10 \\
\hline
\end{tabular}

When Table 1 is examined, it can be seen that especially the 1st- and 2nd-year pre-service teachers did not encounter the concepts of entrepreneurship and entrepreneurship skills in the middle school mathematics curriculum or did not examine the program in this direction. Particularly, all of the 1st-year pre-service teachers stated that they never examined the curriculum in terms of entrepreneurship and entrepreneurship skills. However, towards the 3rd and 4th years of study, the number of pre-service teachers who knew where the concepts of entrepreneurship and entrepreneurship skills occurred in the curriculum began to increase. Despite this increase, there were still pre-service teachers who had not examined the curriculum for entrepreneurship and entrepreneurship skills. The interesting finding was that the 3rd- and 4th-year pre-service teachers who stated that they had encountered the concepts of entrepreneurship and entrepreneurship skills in the curriculum, immediately after the question, "If the concepts of entrepreneurship and entrepreneurship skills were included in the middle school mathematics curriculum, how were these concepts addressed in the curriculum?" was asked, 
10 of the pre-service teachers who answered this question ( 3 of the 3 rd-year teachers, 7 of the 4 th-year teachers, see Table 1), stated that they did not remember where these concepts were encountered. Some examples of the answers given by some of the pre-service teachers to this question are given below.

"I have never examined the concepts you mentioned in the program... "1 st-year pre-service teacher.

"I mean, there are many lessons that we examine in the program, but I have never encountered or seen these concepts before ..." 2nd-year pre-service teacher.

"I know, yes I have seen it, entrepreneurship and entrepreneurship skills were written in a few places ... but I don't know how it was handled, I don't remember ... "3rd-year pre-service teacher.

"Entrepreneurship and entrepreneurship skills are definitely mentioned in the program, I saw it .. but I didn't pay attention to where I saw it and how it was handled (laughs)..." 4th-year pre-service teacher.

In the study, the second question was asked to reveal what the pre-service teachers knew about the basic skills that can be considered together with entrepreneurship skills in the middle school mathematics curriculum. This question asked pre-service teachers, "Are there basic skills that serve entrepreneurship skills in the middle school mathematics curriculum? If so, what do you think is happening and why?". The answers given by the preservice teachers regarding this question are presented in Table 2.

Table 2. Knowledge and state of thinking of the pre-service elementary school mathematics teachers about basic skills that serve entrepreneurship skills in the middle school mathematics curriculum.

Frequency

There are different skills that serve entrepreneurship skills in the middle school mathematics curriculum

\begin{tabular}{|c|c|c|c|c|}
\hline & \\
\hline & $\begin{array}{l}1 \text { st } \\
\text { year }\end{array}$ & $\begin{array}{l}\text { 2nd } \\
\text { year }\end{array}$ & $\begin{array}{l}3 \text { rd } \\
\text { year }\end{array}$ & $\begin{array}{l}\text { 4th } \\
\text { year }\end{array}$ \\
\hline Creativity Skills & & 2 & 7 & 9 \\
\hline Problem & & 2 & 6 & 9 \\
\hline
\end{tabular}

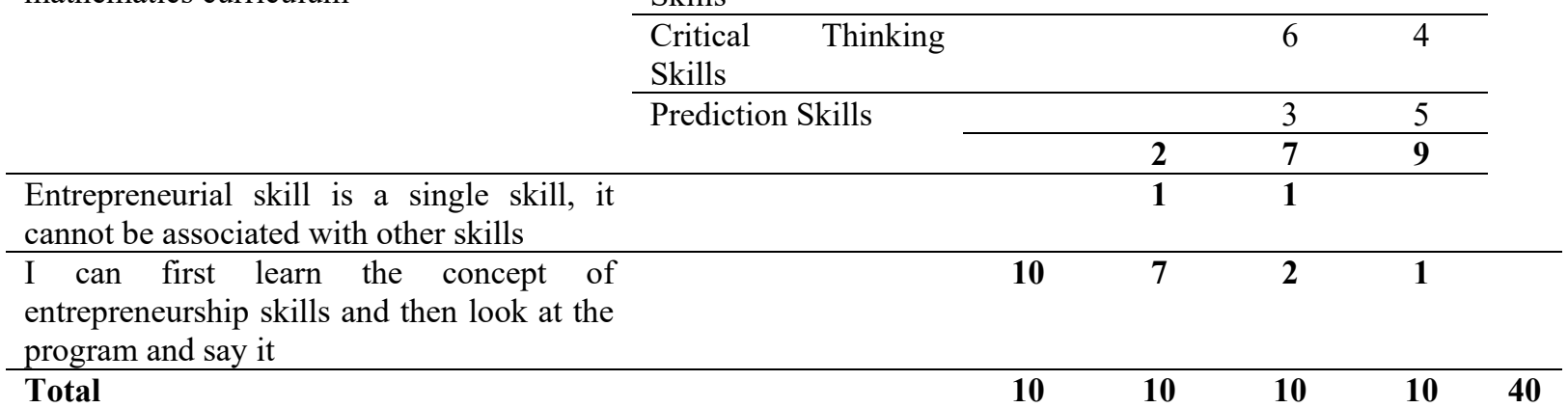

When Table 2 is examined, it can be seen that there were 3 different answers to this question. Half of the pre-service teachers (20 pre-service teachers: 10 of the 1st-year teachers, 7 of the 2 nd-year teachers, 1 of the 3 rdyear teachers, and 1 of the 4th-year teachers) stated that they could answer this question by first learning the concept of entrepreneurship skills and then examining the program. Considering the distribution between the year of study, the number of pre-service teachers who stated that they should have knowledge about entrepreneurship skill decreased towards the 4th year. All of the 1st-year pre-service teachers stated that they should have information on this question. This showed that the pre-service teachers learned about entrepreneurship skills as the year of study progressed. Similarly, the number of pre-service teachers who stated that there were other skills that served entrepreneurship skills in the middle school mathematics curriculum increased as the year of study progressed (18 pre-service teachers: 2 of the 2 nd-year teachers, 7 of the 3 rd-year teachers, and 9 of the 4th-year teachers). Since the same pre-service teachers who counted different skill types gave more than 1 skill example, these numbers were seen a lot in the table. For example, 7 pre-service teachers from the 3rd year stated that there were different skills that served entrepreneurship skills in the middle school mathematics curriculum, but 6 of them counted critical thinking, creative thinking, and problem solving skills, and 4 counted both communication skills and prediction skills. Thus, the numbers in the table are indicated in this direction. Two pre-service teachers, 1 from the 2 nd year and 1 from the $3 \mathrm{rd}$ year, stated that entrepreneurship skills are a single skill and cannot be associated with other skills. Some examples of the answers given by some of the pre-service teachers to this question are given below.

"I do not know entrepreneurship skills exactly, so I have to learn first, I will research and then I will open the program and find its place..." 1st-year pre-service teacher.

"Now, I think the skills should be examined within themselves. To mean entrepreneurship skills is a concept in itself, I cannot think of other skills ..." 2nd-year pre-service teacher. 
"Of course there is, now I think about the skills in the program, entrepreneurship requires creativity, so this skill should have creativity. I think it also requires solutions to problems, that is, it includes problem solving skills (thinking) and it can be considered as a critical thinking skill ... "3-year pre-service teacher.

"Of course, there are basic skills we know in the middle school math program and they serve entrepreneurship skills. Now, once I think that this skill required to be an entrepreneur must be a good communication skill, then we must be a problem-solver to solve the events we encounter, so creativity is never denied, when we have predicted the possible consequences, that's the entrepreneurial skill, all of these skills. it's in the program ... "4th-year pre-service teacher.

3.2. Findings of the Examination of Entrepreneurship and Entrepreneurship Skills as a Course in the Process and in Terms of the Teaching Profession

In the second part of the findings, the lessons that can affect the acquisition of entrepreneurship and entrepreneurship skills and how these concepts can benefit the teaching profession were researched, and the findings obtained from the pre-service elementary mathematics teachers were presented. Third, in the interview questions, "What are the courses that helped you gain entrepreneurship skills?" was posed. The answers given by the pre-service teachers to this question are presented in Table 3.

Table 3. Lessons that help to gain entrepreneurship skills according to pre-service elementary school mathematics teachers.

Lessons $\quad$ How the Lessons Help

\begin{tabular}{|c|c|c|c|c|c|}
\hline & & year & year & year & year \\
\hline All Lessons & $\begin{array}{l}\text { Because each lesson has different } \\
\text { skills it wants to teach }\end{array}$ & & & 1 & 1 \\
\hline Mathematics Lesson & $\begin{array}{l}\text { Because it requires logical inference } \\
\text { and problem solving }\end{array}$ & & & 5 & 7 \\
\hline Turkish Lesson & $\begin{array}{l}\text { Because it provides communication, } \\
\text { diction and oratory skills }\end{array}$ & & 3 & 7 & 7 \\
\hline Sociology-psychology Lessons & $\begin{array}{l}\text { Because it gives social success and } \\
\text { communication skills }\end{array}$ & & 2 & 4 & 8 \\
\hline $\begin{array}{l}\text { I Need to Learn Entrepreneurship } \\
\text { Skills, No Answer }\end{array}$ & & 10 & 7 & 2 & 1 \\
\hline Total & & 10 & 10 & 10 & 10 \\
\hline
\end{tabular}

When Table 3 is examined, it can be seen that half of the pre-service teachers (all of the 1st-year teachers, 7 of the 2nd-year teachers, 2 of the 3rd-year teachers, and 1 of the 1 st-year teachers) stated that they could not answer this question without learning entrepreneurship skills. These findings overlapped with Table 2 (see Table 2). A pre-service teacher from the 3rd and 4th years explained that all of the lessons helped to gain entrepreneurship skills, because each lesson targeted other skills that they wanted to gain. Moreover, 3 of the 2nd-year teachers, 7 of the 3rd-year teachers, and 8 student teachers also gave Mathematics, Turkish, and Sociology-Psychology lessons. The reason for the high number of pre-service teachers who taught these 3 lessons in Table 3 was because, for example, 2 of the 2nd-year pre-service teachers gave both Turkish and Sociology-Psychology lessons. Similarly, 7 of the pre-service teachers from the 4th year gave Mathematics, Turkish, and Sociology-Psychology lessons. The numbers in Table 3 were also determined in this direction. A striking finding in Table 3 was that the pre-service teachers mostly taught mathematics to gain entrepreneurship skills. It can be considered that this finding might have been influenced by the fact that the pre-service teachers selected for the study were pre-service mathematics teachers. In addition, the lessons given in Table 3 and the explanations of how these courses would contribute to gaining entrepreneurship skills were in accordance with skills that can be associated with the entrepreneurship skills in Table 2. Some examples of the answers given by some of the pre-service teachers to this question are given below.

"Frankly, in order to answer this question, I have to learn entrepreneurship skills first ..." 1st-year pre-service teacher.

"I think communication and dialogue with people are very important in entrepreneurship skills. Therefore, Sociology and Psychology lessons can be helpful, and I can also say Turkish lessons for diction and persuasion ... "2nd-year pre-service teacher.

"I think we have to solve problems pretty quickly for this skill, so math lesson is very important in this sense. Well now, there is human factor and communication in this skill, then our Turkish lesson and Sociology lessos should be good too. I think Psychology is also involved when it comes to human factor... "3rd-yeare pre-service teacher.

"I think all of the lessons, because I think that each lesson has its own rules and many skills that you want to teach ..." 4th-yeare pre-service teacher. 
After this question, the pre-service teachers were asked, "How important is having entrepreneurship and entrepreneurship skills for the teaching profession?" All of the pre-service teachers answered this question and stated that it was important. Particularly interesting was that although the 1st-year pre-service teachers stated that they did not have information about entrepreneurship skills, they answered this question by thinking about the entrepreneurs in their lives and their teachers in the past, especially the teachers that they liked. Similarly, the 2nd-, 3rd- and 4th-year pre-service teachers stated that they made comparisons with their teachers from the past. In addition, the importance of the explanations of the pre-service teachers were grouped as "importance for teacher-student" and "importance for teacher-teaching process" and presented in Table 4.

Table 4. Importance of entrepreneurship and entrepreneurial skills from the point of view of the teaching profession.

\begin{tabular}{l|l}
\hline Importance for Teacher-Student & $\begin{array}{l}\text { Importance in Terms of the Teacher-Teaching } \\
\text { Process }\end{array}$ \\
\hline $\begin{array}{l}\text { The teacher, who has entrepreneurship and } \\
\text { entrepreneurship skills, becomes a role model for } \\
\text { her/his students. }\end{array}$ & $\begin{array}{l}\text { A teacher with entrepreneurship and entrepreneurial } \\
\text { skills uses different and new teaching methods. }\end{array}$ \\
\hline $\begin{array}{l}\text { The teacher, who has entrepreneurship and } \\
\text { entrepreneurship skills, trains students who are open } \\
\text { to communication, questioning and self-confident. }\end{array}$ & $\begin{array}{l}\text { A teacher with entrepreneurship and entrepreneurial } \\
\text { skills strives, investigates, queries to make the lesson } \\
\text { more understandable. }\end{array}$ \\
\hline $\begin{array}{l}\text { A teacher with entrepreneurship and entrepreneurial } \\
\text { skills is determined and stable. }\end{array}$ & $\begin{array}{l}\text { A teacher with entrepreneurship and entrepreneurial } \\
\text { skills does not experience lack of materials. }\end{array}$ \\
\hline $\begin{array}{l}\text { A teacher with entrepreneurship and entrepreneurial } \\
\text { skills can keep up with innovations and technology. }\end{array}$ & $\begin{array}{l}\text { A teacher with entrepreneurship and entrepreneurial } \\
\text { skills can adapt their lessons to technology within } \\
\text { their capabilities. }\end{array}$ \\
\hline $\begin{array}{l}\text { A teacher with entrepreneurship and entrepreneurial } \\
\text { skills is sensitive to the social environment. }\end{array}$ & $\begin{array}{l}\text { A teacher with entrepreneurship and entrepreneurial } \\
\text { skills is a good listener and observer in the course } \\
\text { process. }\end{array}$ \\
\hline
\end{tabular}

In Table 4, the findings revealed with regards to the importance of entrepreneurship and entrepreneurial skills in terms of the teaching profession parallel the characteristics that should be in entrepreneurial individuals are presented. Only these features were integrated into the educational process by the teacher candidates and the explanations were reflected in the communication of the teachers with the students and their applications in the teaching process. Some examples of the answers given by some of the pre-service teachers to this question are given below.

"I understood that I need to learn entrepreneurship skills in the previous questions, but now when I associate this question with the teaching profession, I think of my favorite teachers, an example for a teacher student with entrepreneurial skills and I think it allows him to be free in the course ..." 1st-year pre-service teacher.

"So what was entrepreneurship, being creative, being different is very important for teachers with this skill. To give an example, there is a shortage of materials in some village schools, but what does this teacher do, use his creativity and skills and does not have a material shortage ... "4th-year pre-service teacher.

Finally, pre-service teachers were asked whether they had taken a course on entrepreneurship or entrepreneurship skills during their education at the faculty of education. If there were any pre-service teachers who stated that they had taken such a course, immediately after this question, they were asked, "How has this lesson benefited you?". However, all of the 40 pre-service elementary mathematics teachers stated that they had not taken such a course, in addition, the 3rd- and 4th-year pre-service teachers also stated that they saw the courses on these concepts among the elective lessons, but these lessons were not opened because not enough of the students chose this. Some examples of the answers given by some of the pre-service teachers to this question are given below.

"I have never taken a lesson that explained the concepts of entrepreneurship or entrepreneurship skills, maybe we will take it later, but I don't know for now..." 1st-year pre-service teacher.

"No, we have never taken such a lesson ..." 2nd-year pre-service teacher.

"I think I saw it in the elective lessons at the beginning of the term, but I did not choose it, I guess it was not opened ..." 3rd-year pre-service teacher.

"I am in the final year and I have not taken a lesson for entrepreneurship so far. There were elective lessons this year, but it was not opened because many people did not choose it ..." 4th-year pre-service teacher.

\section{Discussion, Conclusion, and Recommendations}

In this study, it was aimed to examine the thoughts and knowledge of pre-service elementary school mathematics teachers about the concepts of entrepreneurship and entrepreneurship skills in terms of the teaching profession, as well as being a lesson to be learned in the middle school mathematics curriculum. According to the findings of the research, it was seen that the 1st- and 2nd-year pre-service teachers did not encounter the concepts of 
entrepreneurship and entrepreneurship skills in the middle school mathematics course program.

Specifically, all the 1st-year pre-service teachers stated that they did not examine the program in this direction. Although the 3rd- and 4th-year students stated that these concepts were used in the curriculum, it was concluded that they did not know where or how they took place. At this point, the education given at the university, especially in the education programs, should be taught and examined from the 1st year. The results of the research showed that the higher the year of study, the more pre-service teachers knew about the curriculum. However, it was seen that this information was insufficient. For this reason, in teacher education, for a detailed examination of the curriculum, the 3rd and 4th year students should not be expected to know it, but a teaching understanding that has been assimilated from the 1 st year. Similar results have emerged in determining the types of skills that can be associated with entrepreneurship skills in the curriculum. Again, all of the 1st-year preservice teachers stated that they should learn entrepreneurship skills first and then examine the program in this direction. The findings showed that the 1st-year pre-service teachers did not know the concept of entrepreneurial skills. This number was similarly high for the 2 nd-year pre-service teachers $(70 \%)$. The 3rd- and 4 th-year preservice teachers were able to associate entrepreneurship skills with the basic skills that they were previously familiar with in the curriculum. However, one of the pre-service teachers still stated that he did not know entrepreneurship skills, even in the 4th year. These results showed that if entrepreneurship and entrepreneurship skills trainings have been provided for pre-service teachers in the education faculty, these trainings were not efficient enough. Similarly, although it was examined in terms of the curriculum, it was seen that the 1 st and $2 \mathrm{nd}$ years education provided insufficient knowledge of the basic skills in the program, and as the year of study increased, the diversity of knowledge about the basic skills also increased. However, unfortunately, this increase was still not considered sufficient to associate with entrepreneurial skills. Pre-service teachers are specified as skills that can be associated with entrepreneurship skills, creativity, problem solving, communication, critical thinking, and prediction skills. Similarly, in the study conducted by Gözübüyük (2008), the development of skills, such as entrepreneurship, creativity, critical thinking, and reflective thinking, were evaluated in parallel, and it was shown that these skills were interrelated and important.

When the lessons that help to gain entrepreneurship skills were examined in this study, unfortunately half of the pre-service teachers (20 pre-service teachers, all in the 1st year) did not answer this question because they did not know the concept of entrepreneurship skills. The results of this question were parallel to the results of the question about relating basic skills to entrepreneurship skills. Two of the pre-service teachers stated that all of the courses were important in gaining entrepreneurship skills. What was interesting was that most of the mathematics lessons were taught by the pre-service teachers. The reason for this was that the mathematics lesson requires logical inference and problem solving skills. After the Mathematics lesson, Turkish, Sociology and Psychology lessons were taught. Since these lessons teach communication, oratory, and human relations, they are thought to be helpful in gaining entrepreneurship skills. Selanik Ay and Acar (2016) stated, in their study with classroom teachers, that classroom teachers teach the lessons that are effective in gaining entrepreneurship skills, such as Life Sciences, Social Studies and Turkish lessons. It was concluded that the course outcomes of these courses were effective in gaining entrepreneurship skills because the lessons are closer to life and to the student. In this study, it can be deduced that the most mathematics lessons are told, that the pre-service teachers are the closest course to them. In addition, it can be stated that they consider the mathematics lesson as a part of life and an indispensable element in the problem solving process.

The importance of having entrepreneurship and entrepreneurship skills for the teaching profession is categorized as importance in terms of the "teacher-student" and "teacher-teaching" processes. In these categories, the teacher-student process includes being a role model for the student in the teacher-student process, raising self-confident students who are open to communication, being determined, being open to innovations and technology, being sensitive to the social environment. In the teacher-teaching process, the characteristics of using different and new teaching methods, striving to make the lesson understandable, not experiencing lack of material, creative, adapting the lesson to technology and being a good listener and observer are listed. The most interesting thing in this question was that all of the pre-service teachers, especially the 1st-year pre-service teachers (although they did not know about entrepreneurship skills), answered the question by considering their past teachers. Akyürek et al. (2013) stated that teachers play an important role in providing students with entrepreneurship skills and the importance of school-family and teachers. In addition, it was stated that elementary school students chose their teachers as role models. Although students are not aware of these results, it can be considered that they have gained some things against entrepreneurship and entrepreneurship skills, especially their teachers are effective at this point. Selanik Ay and Acar (2016) listed the importance of entrepreneurship skills in terms of the teaching profession, as classroom teachers being a role model for students, training students as useful individuals, supporting them in producing different ideas, giving them self-confidence, and enabling them to take risks and cooperating with parents. These results were consistent with the item that pre-service teachers listed for the title "importance for teacher-student process" by a teacher with entrepreneurial skills. 
According to the results of the research, it was determined that none of the 40 pre-service teachers had taken a course on entrepreneurship and entrepreneurship skills, and in addition, the 3rd- and 4th-year pre-service teachers also saw courses on these concepts among elective lessons, but these lessons were not opened because not enough of the students chose this. In order for entrepreneurship and entrepreneurship skills to be included and supported more in the education process, students should be enthusiastic in this field and should include these concepts, both under the title of elective lessons and as a lesson. In the study of Bacanak (2013), the methods and techniques used to gain entrepreneurship skills were given as experiments, drama, group work, and interviews. In the drama lessons at the university level, the teaching of entrepreneurship and entrepreneurship skills and the studies of gaining them for individuals can be included. In addition, as Clegg et al. (2005) stated, students are expected to turn their entrepreneurship education into practice with entrepreneurship education. At this point, it can be expected that pre-service teachers who began to have entrepreneurship and entrepreneurship education in their first year, will turn this training into practice in the internship lessons that they attend in their final year. In this sense, it may be considered to include entrepreneurship trainings in other Faculties, especially in Education Faculties other than Economics, Administrative Sciences, and Business Faculties. In addition, as Solomon stated, the essence of entrepreneurship education should reflect reality (Solomon, 2007). Based on this definition, former graduates who have achieved success in entrepreneurship education at university, and who have achieved success in different places, can be invited into the classroom environment and their experiences can be shared with pre-service teachers.

The concepts of entrepreneurship and entrepreneurship skills, whose place and importance are increasing day by day, should be included more in the curriculum, at this point, the acquisitions for entrepreneurship skills should be specifically stated and activities should be designed. In order for pre-service teachers to have a better command of the curriculum, the curriculum should be included in the education lessons from the first year of the undergraduate program, even if it is for promotional purposes. The results of the research can be compared by conducting this research in different universities, in the same department, and with different numbers of preservice teachers.

\section{References}

Ağca, V., 2007. Avrupa Birliğinin girişimcilik politikası ve Türkiye'ye yansımaları. (Ed. M. Kurt ve S. Bayraktaroğlu). Türkiye'de işletmecilikte yeni perspektifler. 169-194. Ankara: Gazi Kitabevi.

Akyürek, Ç., 2013. İlkokul Öğretmenlerinin Girişimcilik Becerisine İlişkin Görüşlerinin Değerlendirilmesi, PhD Thesis, Çanakkale Onsekiz Mart University, Çanakkale.

Ay S. T., \& Acar Ş., 2016. Views of classroom teachers about the acquisition of entrepreneurial skills. Electronic Journal of Social Science, 58: 960-976.doi: 10.17755/esosder.03138.

Bacanak A., 2013. Teachers' views about science and technology lesson effects on the development of students' entrepreneurship skills. Educational Sciences: Theory \& Practice, 13(1): 622-629.

Bilge H., \& Bal V., 2012. Girişimcilik eğilimi: Celal Bayar Üniversitesi öğrencileri üzerine bir araştırma. Süleyman Demirel Üniversitesi Sosyal Bilimler Enstitüsü Dergisi, 2 (16): 131-148.

Bozkurt Ö., 2007. Girişimcilik Eğiliminde Kişilik Özelliklerinin Önemi,Çanakkale Onsekiz Mart Üniversitesi Girişimcilik ve Kalkınma Dergisi, 2: 93-111, Retrieved 1 December 2020, from: http://acikerisim.lib.comu.edu.tr:8080/xmlui/handle/COMU/982.

Bozkurt Ö., 2011. Dünyada ve Türkiye’de Girişimcilik Eğitimi: Başarılı Girişimciler ve Öğretim Üyelerinden Öneriler, Detay Yayıncılık, Ankara.

Bulut, Ç., \& Aslan, G., 2014. Üniversitelerde Girişimcilik Eğitimi, Sosyal Ekonomik Araştırmalar Dergisi, 27, $(1-20)$.

Clegg, S. R., Cunha, J. V., \& Cunha, M. P., 2002. Management Paradoxes: A Relational View, Human Relations, 55(5), 483-503.

Commission of the European Communities, 2006. Adult Learning: It Is Never Too Late to

Learn. From: http://europa.eu/legislation / [Accessed: 10/02/2018]

Ergüven, S., 2011. Öğretmenlerin yansıtıcı düşünme becerilerinin çeşitli değişkenler açısından incelenmesi. $\mathrm{PhD}$ Thesis. Niğde University, Niğde.

Fayolle, A., Benoît G., \& Narjisse L., 2006. Assessing The Impact of Entrepreneurship Education Programs: A New Methodology, Journal of European Industrial Training, 30(9), 701-20.

Figel, J., 2006. Key competences for lifelong learning. Education and Training, [Online] Available at: http://ec.europa.eu/dgs/education_culture/publ/pdf/ll-learning/keycomp_en.pdf

Finkle, T. A., Donald F. K., \& Michael G. G., 2006. An Examination Of Entrepreneurship Centers In The United States: A National Survey, Journal of Small Business Management, 44(2), 184-206.

Gözübüyük, D., 2019. Yaratıcı, eleştirel ve yansıtıcı düşünmenin girişimcilik becerisi üzerine etkisi. PhD Thesis, Bartın University, Bartın.

Hisrich, R. D., \& Peters, M. P., 1998. Enterpreneurship, (4th. ed.). Boston: McGraw Hill. 
İșcan O., \& Kaygın E., 2011. Potansiyel girişimciler olarak üniversite öğrencilerinin

Girişimcilik eğilimlerini belirlemeye yönelik bir araştırma. Organizasyon ve Yönetim

Bilimleri Dergisi. 3(2):275-286

Korkmaz O., 2012. Üniversite öğrencilerinin girişimcilik eğilimlerini belirlemeye yönelik bir araştırma: Bülent Ecevit Üniversitesi örneği. Afyon Kocatepe Üniversitesi İktisadi ve İdari Bilimler Fakültesi Dergisi, 14 (2): 209-226

Lee S. M., \& Peterson S., 2000. Culture, entrepreneurial orientation, and global competitiveness. Journal of World Business, 35: 401-416. Retrieved: 8 December 2020, from: https://doi.org/10.1016/S10909516(00)00045-6

Milli Eğitim Bakanlığı [Ministery of National Education-MoNE], 2005. Matematik Dersi Öğretim Programı). T.C. Millî Eğitim Bakanlığı, Ankara, Turkey

Milli Eğitim Bakanlığı [Ministery of National Education-MoNE], 2013. Matematik Dersi Öğretim Programı). T.C. Millî Eğitim Bakanlığı, Ankara, Turkey

Milli Eğitim Bakanlığı [Ministery of National Education-MoNE], 2018. Matematik Dersi Öğretim Programı (İlkokul ve Ortaokul1, 2, 3, 4, 5, 6, 7 ve 8. Sınıflar). T.C. Millî Eğitim Bakanlığı, Ankara, Turkey

Özdemir P., 2016. Girişimci üniversiteler ve Türkiye'de girişimcilik eğitimi, PhD Thesis, University of Maltepe, İstanbul

Pan V. L., \& Akay C., 2015. Eğitim fakültesi öğrencilerinin girişimcilik düzeylerinin çeşitli değişkenler açısından incelenmesi. Education Sciences, 9 (6):125-138

Sanchez, J. C., 2013. The Impact of an Entrepreneurship Education Program on Entrepreneurial Competencies and Intention, Journal of Small Business Management, 51(3), 447-465.

Schumpeter, J. A., 1991. The economics and sociology of capitalism. New Jersey: Prinston University Pres.

Solomon, G., 2007. An Examination of Entrepreneurship Education in the United States, Journal of Small Business and Enterprise Development, 14(2), 168-182.

Uygun M., Mete S., \& Güner E., 2012. Genç Girişimci Adayların Girişimcilik Eğilimi ve Girişimcilik Özellikleri Arasındaki İlişkiler. Organizasyon ve Yönetim Bilimleri Dergisi, 2(4): 145-156

Wang C., \& Wong P., 2004. Entrepreneurial Interest in University Students in Singapore. Technovation 24(2): 163—72, Retrieved: 12 November 2020, from: https://doi.org/10.1016/S0166-4972(02)00016-0. 